\title{
Abscisic acid accumulation and cadmium tolerance in rice seedlings
}

\author{
Yi Ting Hsu and Ching Huei Kao* \\ Department of Agronomy, National Taiwan University, Taipei, Taiwan
}

\author{
Correspondence \\ *Corresponding author, \\ e-mail: kaoch@ntu.edu.tw
}

Received 6 September 2004; revised 8 January 2005

doi: 10.1111/j.1399-3054.2005.00490.x
Rice (Oryza sativa L.) seeds were soaked for $18 \mathrm{~h}$ in distilled water in the absence (-PBZ) or presence (+PBZ, a triazole) of $100 \mathrm{mg} \mathrm{I}^{-1}$ paclobutrazol and then air dried. These air-dried seeds were germinated in the dark and then cultivated in a Phytotron. Twelve-day-old -PBZ and +PBZ seedlings were treated or not with $\mathrm{CdCl}_{2}$. Cd toxicity was judged by the decrease in biomass production, decrease in chlorophyll and protein content, increase in $\mathrm{NH}_{4}{ }^{+}$content and induction of oxidative stress. The results indicated that PBZ applied to seeds was able to protect rice seedlings from $\mathrm{Cd}$ toxicity. On treatment with $\mathrm{CdCl}_{2}$, the abscisic acid (ABA) content increased in + PBZ leaves, but not in -PBZ leaves. The decrease in the transpiration rate of $-\mathrm{PBZ}$ seedlings by $\mathrm{CdCl}_{2}$ was less than that of $+\mathrm{PBZ}$ seedlings. Exogenous application of the ABA biosynthesis inhibitor, fluridone (Flu), reduced ABA accumulation, increased the transpiration rate and $\mathrm{Cd}$ content, and decreased the $\mathrm{Cd}$ tolerance of + PBZ seedlings. The effects of Flu on the $\mathrm{Cd}$ toxicity, transpiration rate and $\mathrm{Cd}$ content were reversed by the application of ABA. It seems that the PBZ-induced Cd tolerance of rice seedlings is mediated through an accumulation of ABA.

\section{Introduction}

Paclobutrazol [PBZ, (2RS,3RS)-1-(4-chlorophenyl)-4,4dimethyl-2-(1,2,4-triazolyl)-pentan-3-ol], a member of the triazole plant growth regulator group, is an inhibitor of gibberellin (GA) biosynthesis (Graebe 1987, Rademacher et al. 1987, Davis and Curry 1991) and a retardant of shoot growth (Cox and Keever 1988, Davis et al. 1988, Davis and Curry 1991). The primary mode of action of PBZ is inhibition of ent-kaurene oxidase to ent-kaurenoic acid in the early pathway of GA biosynthesis (Graebe 1987, Rademacher et al. 1987). PBZ has been used to provide plant protection against environmental stresses, such as chilling (Whitaker and Wang 1987, Lurie et al. 1994, Pinhero and Fletcher 1994,
Pinhero et al. 1997), heat (Kraus and Fletcher 1994, Pinhero and Fletcher 1994, Kraus et al. 1995, Gilley and Fletcher 1998, Vettakkorumakankav et al. 1999), flooding (Webb and Fletcher 1996), salt (Abou El-Khashab et al. 1997) and gaseous sulphur dioxide (Lee et al. 1985).

Cadmium (Cd) is a heavy metal that is toxic to humans, animals and plants, and is a widespread pollutant with a long biological half-life (Wagner 1993). This metal enters the environment mainly from industrial processes and phosphate fertilizers and is transferred to animals and humans through the food chain (Wagner 1993). Taken up in excess by plants, Cd directly or indirectly inhibits physiological processes, such as

Abbreviations - ABA, abscisic acid; AOS, active oxygen species; APX, ascorbate peroxidase; ASC, ascorbate; CAT, catalase; d. wt., dry weight; ELISA, enzyme-linked immunosorbent assay; Flu, fluridone; f. wt., initial fresh weight; GA, gibberellin; GR, glutathione reductase; GS, glutamine synthetase; GSH, reduced glutathione; MDA, malondialdehyde; PAL, phenylalanine ammonia-lyase; PBZ, paclobutrazol; POX, peroxidase; SOD, superoxide dismutase; TN1, Taichung Native 1. 
respiration, photosynthesis, cell elongation, plant-water relationships, nitrogen metabolism and mineral nutrition, resulting in poor growth and low biomass (Sanitá di Toppi and Gabbrielli 1999).

In Taiwan, inappropriate disposal of industrial waste has given rise to widespread $\mathrm{Cd}$ contamination of irrigated water (higher than $10 \mathrm{mg} \mathrm{I}^{-1}$ ). Thus, there is an urgent need to study the mechanism of $\mathrm{Cd}$ tolerance of rice plants.

It has been demonstrated that uniconazole, another potent member of the triazole family, induces $\mathrm{Cd}$ tolerance in wheat (Singh 1993). However, this is the only report describing the protective effect of triazole against $\mathrm{Cd}$ toxicity. Here, we show that PBZ protects rice seedlings from $\mathrm{Cd}$ toxicity, confirming the ability of PBZ to induce stress tolerance in plants.

In higher plants, abscisic acid (ABA) is a well-known stress hormone leading to the induction of various protective reactions, which are adaptations for coping with abiotic environmental stresses, such as ozone (Lin et al. 2001), freezing (Guy 1990), chilling (Lee et al. 1993), drought (Zeevaart and Creelman 1988) and salt (La Rosa et al. 1987). Recently, a role of ABA in the Cd tolerance of rice seedlings has been demonstrated ( $\mathrm{Hsu}$ and Kao 2003a, 2003b, Kuo and Kao 2004). We found that rice seedlings of cultivar Tainung 67 were more tolerant to $\mathrm{Cd}$ than were those of cultivar Taichung Native 1 (TN1), and the increase in endogenous $\mathrm{ABA}$ content was closely related to the $\mathrm{Cd}$ tolerance of rice seedlings (Hsu and Kao 2003a). It is not known whether PBZinduced $\mathrm{Cd}$ tolerance of rice seedlings is mediated through $A B A$ accumulation. Thus, we also investigated the role of $\mathrm{ABA}$ in the PBZ-induced Cd tolerance of TN1 rice seedlings.

\section{Materials and methods}

\section{Plant material and treatment}

Rice (Oryza sativa L., cv. TN1) seeds were sterilized with $2.5 \%$ sodium hypochlorite for $15 \mathrm{~min}$ and washed extensively with distilled water. These seeds were soaked for $18 \mathrm{~h}$ at room temperature in $100 \mathrm{mg} \mathrm{I}^{-1}$ PBZ or in distilled water (-PBZ), as described by Fletcher and Hosfsta (1990), and then were air dried for 5 days. These air-dried seeds were then germinated in Petri dishes with wet filter papers at $37^{\circ} \mathrm{C}$ in the dark. After $48 \mathrm{~h}$ of incubation, uniformly germinated seeds were selected and cultivated in a $250 \mathrm{ml}$ beaker containing half-strength Kimura $B$ solution including the following macro- and microelements: $182.3 \mu \mathrm{M}$ $\left(\mathrm{NH}_{4}\right)_{2} \mathrm{SO}_{4}, 91.6 \mu \mathrm{M} \mathrm{KNO}_{3}, 273.9 \mu \mathrm{M} \mathrm{MgSO}_{4} \cdot 7 \mathrm{H}_{2} \mathrm{O}$, $91.1 \mu \mathrm{M} \quad \mathrm{KH}_{2} \mathrm{PO}_{4}, \quad 182.5 \mu \mathrm{M} \quad \mathrm{Ca}\left(\mathrm{NO}_{3}\right)_{2}, \quad 30.6 \mu \mathrm{M}$
Fe-citrate, $0.25 \mu M \quad \mathrm{H}_{3} \mathrm{BO}_{3}, \quad 0.2 \mu M \quad \mathrm{MnSO}_{4} \cdot \mathrm{H}_{2} \mathrm{O}$, $0.2 \mu M \quad \mathrm{ZnSO}_{4} .7 \mathrm{H}_{2} \mathrm{O}, \quad 0.05 \mu M \quad \mathrm{CuSO}_{4} \cdot 5 \mathrm{H}_{2} \mathrm{O}$ and $0.07 \mu \mathrm{M} \mathrm{H}_{2} \mathrm{MoO}_{4}$ (Chu and Lee 1989). The hydroponically cultivated seedlings were grown in a Phytotron (Agricultural Experimental Station, National Taiwan University, Taipei, Taiwan) with natural sunlight at $30^{\circ} \mathrm{C}$ (day) $/ 25^{\circ} \mathrm{C}$ (night) and $90 \%$ relative humidity. Twelve-day-old seedlings with three leaves were used in all experiments.

For $\mathrm{Cd}, \mathrm{ABA}$ or fluridone (Flu) treatment, 12-day-old seedlings were grown in basic nutrient solution plus $1.5 \mathrm{mMCdCl} 2,5 \mu \mathrm{MABA}$ or $0.2 \mathrm{mM}$ Flu.

\section{Growth analysis}

At the end of treatment, the seedlings were divided into their separate parts (shoot, adventitious roots and primary roots). The length of the shoot and primary roots and the fresh weight (f. wt.) of the shoot and roots (adventitious roots plus primary roots) were then measured. For dry weight (d. wt.) estimation, the shoot and roots were dried at $65^{\circ} \mathrm{C}$ for $48 \mathrm{~h}$.

\section{Cd determination}

For the determination of $\mathrm{Cd}$, leaves were dried at $65^{\circ} \mathrm{C}$ for $48 \mathrm{~h}$. Dried material was ashed at $550^{\circ} \mathrm{C}$ for $20 \mathrm{~h}$. The ash residue was incubated with $31 \% \mathrm{HNO}_{3}$ and $17.5 \% \mathrm{H}_{2} \mathrm{O}_{2}$ at $72^{\circ} \mathrm{C}$ for $2 \mathrm{~h}$, and dissolved in distilled water. $\mathrm{Cd}$ was then quantified using an atomic absorption spectrophotomer (Model AA-6800, Shimadzu, Kyoto, Japan). The amount of $\mathrm{Cd}$ was expressed on a d. wt. basis.

\section{Determination of chlorophyll, protein, $\mathrm{NH}_{4}{ }^{+}$, malondialdehyde (MDA), ascorbate (ASC) and reduced glutathione (GSH)}

The chlorophyll content was determined according to Wintermans and De Mots (1965) after extraction in 96\% $(\mathrm{v} / \mathrm{v})$ ethanol. For protein determination, leaves were homogenized in a $50 \mathrm{mM}$ sodium phosphate buffer $(\mathrm{pH}$ 6.8). The extracts were centrifuged at $17600 \mathrm{~g}$ for $20 \mathrm{~min}$, and the supernatants were used for determination by the method of Bradford (1976). $\mathrm{NH}_{4}{ }^{+}$was measured in the crude extract by the Berthelot reaction, modified according to Weatherburn (1967). The detailed procedure has been described previously (Lin and Kao 1996). MDA, routinely used as an indicator of lipid peroxidation, was extracted with $5 \%(\mathrm{w} / \mathrm{v})$ trichloroacetic acid and determined according to Heath and Packer (1968). ASC in 5\% (w/v) trichloroacetic acid 
and $\mathrm{GSH}$ in 3\% sulphosalicylic acid extract were determined as described by Laws et al. (1983) and Smith (1985), respectively.

\section{Enzyme extraction and assays}

For the extraction of enzymes, leaf tissues were homogenized with $0.1 \mathrm{M}$ sodium phosphate buffer ( $\mathrm{pH}$ 6.8) in a chilled pestle and mortar. The homogenate was centrifuged at $12000 \mathrm{~g}$ for $20 \mathrm{~min}$ and the resulting supernatant was used for the determination of the enzyme activity. The whole extraction procedure was carried out at $4^{\circ} \mathrm{C}$. Superoxide dismutase (SOD) was determined according to Paoletti et al. (1986). One unit of SOD was defined as the amount of enzyme that inhibited by $50 \%$ the rate of $\mathrm{NADH}$ oxidation observed in a blank sample. Peroxidase (POX) activity was measured using a modification of the procedure of MacAdam et al. (1992). The activity was calculated using the extinction coefficient $\left(26.2 \mathrm{mM}^{-1} \mathrm{~cm}^{-1}\right.$ at $470 \mathrm{~nm}$ ) for tetraguaiacol. One unit of POX was definedas the amount of enzyme that caused the formation of $1 \mu \mathrm{mol}$ tetraguaiacol per minute. Glutamine synthetase (GS) was assayed by the method of Oaks et al. (1980). One unit of GS was defined as the amount of enzyme that caused the formation of $1 \mu \mathrm{mol}$ L-glutamate $\gamma$-monohydroxamate per minute. Phenylalanine ammonia-lyase (PAL) was extracted and determined according to Hyodo and Fujinami (1989). The activity was calculated using the extinction coefficient $\left(9500 \mathrm{M}^{-1} \mathrm{~cm}^{-1}\right.$ at $290 \mathrm{~nm}$ ) for trans-cinnamate. One unit of PAL was defined as the amount of enzyme that caused the formation of $1 \mu \mathrm{mol}$ transcinnamate per hour.

\section{ABA determination}

For the extraction of $\mathrm{ABA}$, leaves were homogenized with a pestle and mortar in extraction solution $(80 \%$ methanol containing $2 \%$ glacial acetic acid). To remove plant pigments and other non-polar compounds which could interfere in the immunoassay, extracts were first passed through a polyvinylpyrrolidone column and C18 cartridges. The eluates were concentrated to dryness by vacuum evaporation and resuspended in Tris-buffered saline before enzyme-linked immunosorbent assay (ELISA). ABA was quantified by ELISA (WalkerSimmons 1987). The ABA immunoassay detection kit (PGR-1) was purchased from Sigma Chemical Co. (St. Louis, MO) and was specific for (+)-ABA. By evaluating ${ }^{3} \mathrm{H}$-ABA recovery, $\mathrm{ABA}$ loss was less than $3 \%$ by the method described here.

\section{Transpiration rate}

The transpiration rate was measured according to Greger and Johansson (1992). The transpiration rate was calculated from the water loss during each interval and converted to a per day per seedling basis.

\section{Expression of data and statistical analysis}

In the present study, the third leaves of rice seedlings were used to determine chlorophyll, protein, $\mathrm{NH}_{4}{ }^{+}$, MDA, ASC, GSH and ABA. As the f. wt. of -PBZ leaves was no different from that of +PBZ leaves, data were expressed on the basis of initial fresh weight (f. wt.). Statistical differences between measurements $(n=4)$ for different treatments or for different times were analysed following the LSD test.

\section{Results}

\section{Growth analysis}

PBZ-treated rice seedlings exhibited typical characteristics of triazole treatment, such as reduced shoot length and $f$. wt. and enhanced primary root length (Table 1; Pinhero and Fletcher 1994). Shoot d. wt., root d. wt. and root f. wt. of PBZ-treated rice seedlings were not significantly different from those of the controls (-PBZ) (Table 1). Less adventitious roots were visually observed in +PBZ than in -PBZ seedlings. Both adventitious roots and primary roots were used to determine the f. wt. and d. wt. of roots. This may explain why the $d$. wt. and f. wt. of +PBZ roots were not significantly different from those of -PBZ roots.

\section{Evaluation of $\mathrm{Cd}$ toxicity}

\section{Biomass production}

$\mathrm{Cd}$ is readily taken up by rice seedlings, leading to growth reduction (Chen and Kao 1995). Thus, in the

Table 1. Growth analysis of rice seedlings 12 days after planting. Seeds were soaked for $18 \mathrm{~h}$ in water (-PBZ) or PBZ (+PBZ) and dried. The seedlings were cultivated for 12 days in a Phytotron with natural sunlight at $30^{\circ} \mathrm{C}$ (day) $/ 25^{\circ} \mathrm{C}$ (night) and $90 \%$ relative humidity. Significant difference at ${ }^{\mathrm{a}} P<0.01$ and ${ }^{\mathrm{b}} P<0.05$, respectively. PBZ, paclobutrazol.

\begin{tabular}{lrr}
\hline Parameter & \multicolumn{1}{c}{-PBZ } & \multicolumn{1}{c}{+ PBZ } \\
\hline Shoot length $(\mathrm{cm})$ & $13.7 \pm 0.3$ & $9.4 \pm 0.1^{\mathrm{a}}$ \\
Root length $(\mathrm{cm})$ & $7.9 \pm 0.2$ & $13.2 \pm 0.3^{\mathrm{a}}$ \\
Shoot fresh weight $\left(\mathrm{mg} \mathrm{seedling}^{-1}\right)$ & $53.6 \pm 3.1$ & $44.0 \pm 1.7^{\mathrm{b}}$ \\
Shoot dry weight $\left(\mathrm{mg} \mathrm{seedling}^{-1}\right)$ & $12.7 \pm 0.2$ & $12.9 \pm 0.1$ \\
Root fresh weight $\left(\mathrm{mg} \mathrm{seedling}^{-1}\right)$ & $47.1 \pm 3.9$ & $40.5 \pm 3.2$ \\
Root dry weight $\left(\mathrm{mg} \mathrm{seedling}^{-1}\right)$ & $6.1 \pm 0.4$ & $6.7 \pm 0.2$ \\
\hline
\end{tabular}


present study, $\mathrm{Cd}$ toxicity was first evaluated by biomass production (shoot and root d. wt.). The effect of $\mathrm{CdCl}_{2}$ concentration on shoot and root $d$. wt. of rice seedlings is presented in Fig. 1. In -PBZ seedlings, the shoot d. wt. was decreased by $0.5 \mathrm{mM} \mathrm{CdCl} 2$ and no further decrease was observed at 1 and $1.5 \mathrm{mM}$ (Fig. 1A). However, $\mathrm{CdCl}_{2}(0.5-1.5 \mathrm{mM})$ had no effect on the shoot d. wt. of +PBZ seedlings (Fig. 1B). Increasing concentrations of $\mathrm{CdCl}_{2}$ from 0.5 to $1.5 \mathrm{mM}$ progressively decreased the root $d$. wt. of -PBZ seedlings, but had no effect on the root d. wt. of +PBZ rice seedlings. Fig. 2 shows the time courses of biomass production of -PBZ and + PBZ seedlings in the presence or absence of $1.5 \mathrm{mM} \mathrm{CdCl}$. The d. wt. of the shoot and roots of PBZ seedlings treated with $\mathrm{CdCl}_{2}$ was significantly lower than that of the -PBZ seedlings not treated with $\mathrm{CdCl}_{2}$. However, the d. wt. of the shoot and roots of $+\mathrm{PBZ}$ seedlings was only slightly affected by $\mathrm{CdCl}_{2}$. All of these results suggest that + PBZ seedlings are $\mathrm{Cd}$ tolerant.

\section{Chlorophyll and protein loss}

In plants, the most general symptom of Cd toxicity is chlorosis (Das et al. 1997). In previous work, we have shown that rice seedlings treated with $\mathrm{CdCl}_{2}$ at high $(0.5$ - $1.5 \mathrm{mM})$ and low $(10-50 \mu \mathrm{M})$ concentrations show chlorosis and protein loss ( $\mathrm{Hsu}$ and Kao 2003a). However, a longer period (more than 6 days) was

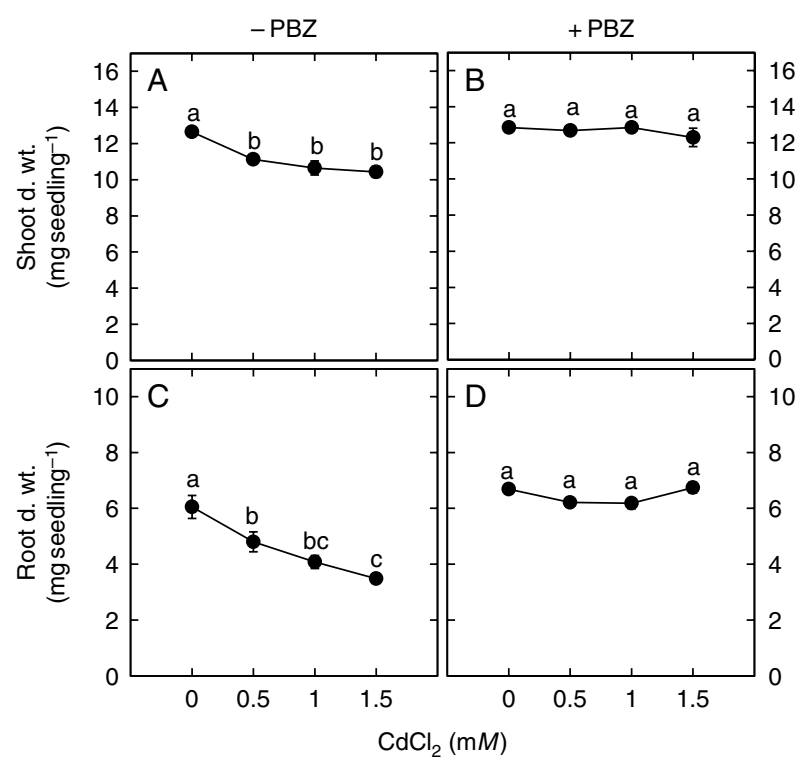

Fig. 1. Effect of $\mathrm{CdCl}_{2}$ concentration on the dry weight (d. wt.) of shoot $(A, B)$ and roots $(C, D)$ of $-P B Z$ and $+P B Z$ rice seedlings ( $P B Z$, paclobutrazol). The $d$. wt. of shoot and roots were measured 2 days after treatment. Bars indicate the standard error $(n=4)$. Values with the same letter are not significantly different at $P<0.05$.

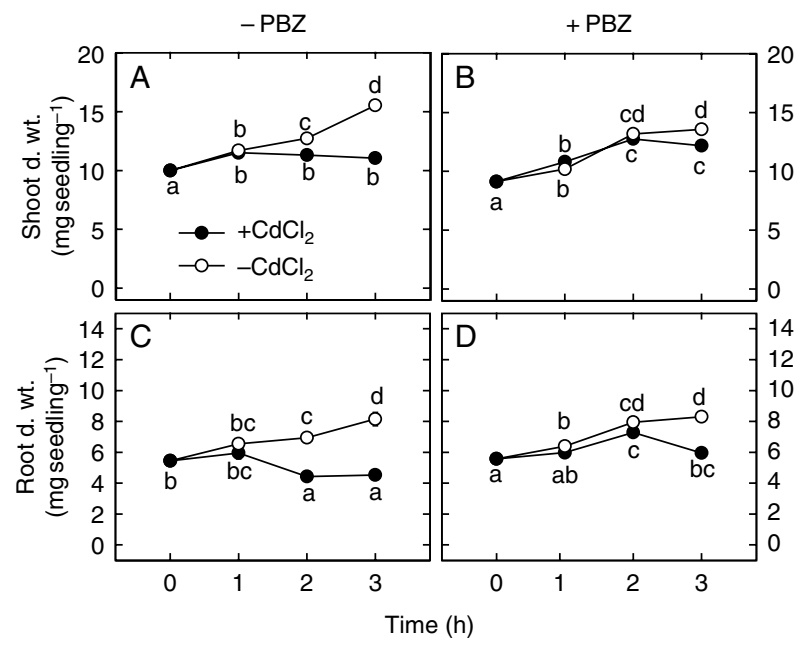

Fig. 2. Changes in the dry weight (d. wt.) of shoot $(A, B)$ and roots ( $C$, D) of $-P B Z$ and $+P B Z$ rice seedlings ( $P B Z$, paclobutrazol) in the presence or absence of $\mathrm{CdCl}_{2}(1.5 \mathrm{mM})$. Bars indicate the standard error $(n=4)$. Values with the same letter are not significantly different at $P<0.05$.

required to show chlorosis when rice seedlings were treated with low concentrations of $\mathrm{CdCl}_{2}$ ( $\mathrm{Hsu}$ and Kao 2003a). When seedlings were treated with $0.5 \mathrm{mM} \mathrm{CdCl}$, chlorosis was first shown in the second leaves, but not the third leaves, of rice seedlings in a short-term experiment (3 days) (Hsu and Kao 2004). In order to show chlorosis in the third leaves in a shortterm experiment, $1.5 \mathrm{mM} \mathrm{CdCl} 2$ was required. Thus, in the present study, $\mathrm{Cd}$ toxicity in the third leaves exposed to $1.5 \mathrm{mM} \mathrm{CdCl}$ was assessed by the decrease in chlorophyll and protein content. A marked decrease in chlorophyll and protein was observed in -PBZ leaves after $\mathrm{Cd}$ treatment (Fig. 3A,C). In contrast, only a slight decrease in chlorophyll and protein content caused by $\mathrm{CdCl}_{2}$ was observed in +PBZ leaves (Fig. 3B,D).

\section{$\mathrm{NH}_{4}{ }^{+}$accumulation}

$\mathrm{NH}_{4}{ }^{+}$is a central intermediate of nitrogen metabolism in plants (Miflin and Lea 1976), but a high content of $\mathrm{NH}_{4}{ }^{+}$is known to have toxic effects on plant cells (Givan 1979). Recent studies have demonstrated that $\mathrm{NH}_{4}{ }^{+}$accumulation in the leaves of rice seedlings is linked to $\mathrm{Cd}$ toxicity (Hsu and Kao 2003b). In this study, we showed that, on treatment with $\mathrm{CdCl}_{2}$, the $\mathrm{NH}_{4}{ }^{+}$ content increased markedly in -PBZ leaves (Fig. 4A), but only slightly in $+\mathrm{PBZ}$ leaves (Fig. 4B). These results suggest that PBZ protects rice seedlings from $\mathrm{NH}_{4}{ }^{+}$ accumulation caused by $\mathrm{Cd}$ toxicity.

GS is the key enzyme in $\mathrm{NH}_{4}{ }^{+}$assimilation and catalyses the ATP-dependent condensation of $\mathrm{NH}_{4}{ }^{+}$ 


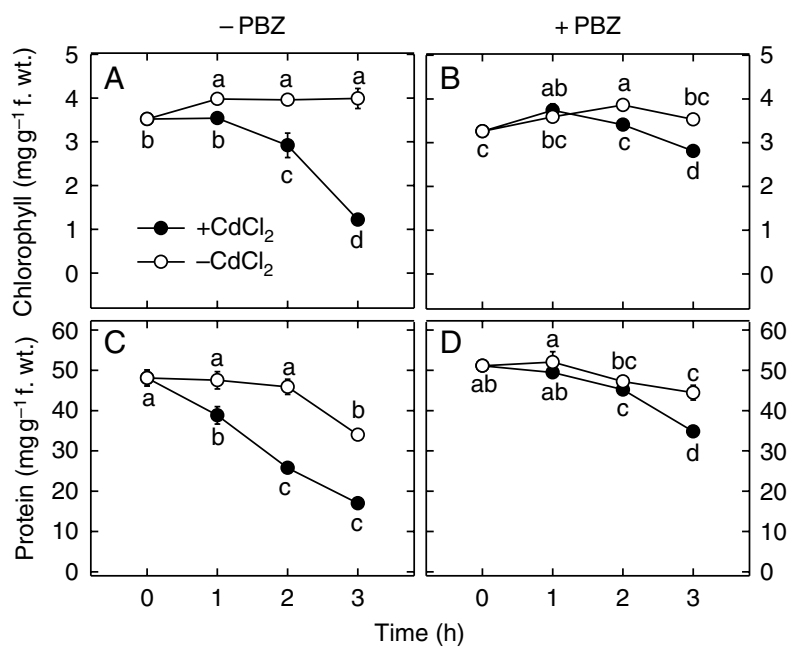

Fig. 3. Changes in the contents of chlorophyll $(A, B)$ and protein $(C, D)$ in the third leaves of -PBZ and +PBZ rice seedlings (PBZ, paclobutrazol) in the presence or absence of $\mathrm{CdCl}_{2}(1.5 \mathrm{mM})$. Bars indicate the standard error $(n=4)$. Values with the same letter are not significantly different at $P<0.05$. f. wt., fresh weight.

with glutamate to produce glutamine (Miflin and Lea 1976). PAL catalyses the elimination of $\mathrm{NH}_{4}^{+}$ from phenylalanine and produces trans-cinnamate (Hahlbrock and Grisebach 1979). $\mathrm{NH}_{4}{ }^{+}$released from PAL reaction has been shown to be trapped in glutamine molecules by the action of GS (Razel et al. 1996, Van Heerden et al. 1996). Sakurai et al. (2001) have provided evidence to show that GS is partly coupled to the reaction of PAL in developing rice leaves. Previous

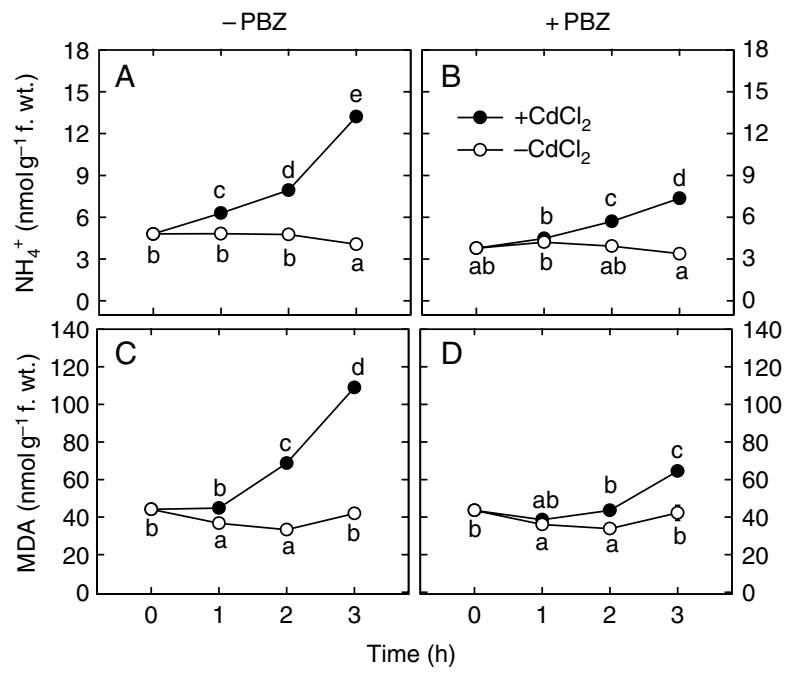

Fig. 4. Changes in the contents of $\mathrm{NH}_{4}{ }^{+}(\mathrm{A}, \mathrm{B})$ and malondialdehyde (MDA) (C, D) of $-\mathrm{PBZ}$ and $+\mathrm{PBZ}$ rice seedlings (PBZ, paclobutrazol) in the presence or absence of $\mathrm{CdCl}_{2}(1.5 \mathrm{mM})$. Bars indicate the standard error $(n=4)$. Values with the same letter are not significantly different at $P<0.05$. f. wt., fresh weight. work has indicated that PAL and GS are the enzymes responsible for $\mathrm{NH}_{4}^{+}$accumulation in rice leaves caused by $\mathrm{Cd}$ toxicity (Hsu and Kao 2003b). In this study, we demonstrated that the increase in PAL specific activity and the decrease in GS activity caused by $\mathrm{CdCl}_{2}$ were more pronounced in -PBZ than in + PBZ leaves (Fig. 5A,B). These results further support the conclusion that PBZ-treated seedlings are $\mathrm{Cd}$ tolerant.

$\mathrm{NH}_{4}{ }^{+}$can also be produced during nitrate reduction and photorespiration (Miflin and Lea 1976). It is not known whether $\mathrm{NH}_{4}{ }^{+}$accumulation in rice leaves caused by $\mathrm{Cd}$ toxicity is mediated via the promotion of nitrate reduction and photorespiration. Further research in this area is likely to be highly rewarding.

\section{Oxidative stress}

Unlike $\mathrm{Cu}$ and $\mathrm{Fe}, \mathrm{Cd}$ is not a redox metal, and therefore cannot catalyse Fenton-type reactions yielding active oxygen species (AOS). However, $\mathrm{Cd}$ can induce oxidative stress indirectly by producing a disturbance in chloroplasts. Thus, $\mathrm{Cd}$ produces the degradation of chlorophyll and carotenoids, as well as an inhibition of their biosynthesis (Bazzaz et al. 1974), which can produce disturbances in the electron transport rates of PSI and PSII, leading to the generation of AOS. In a

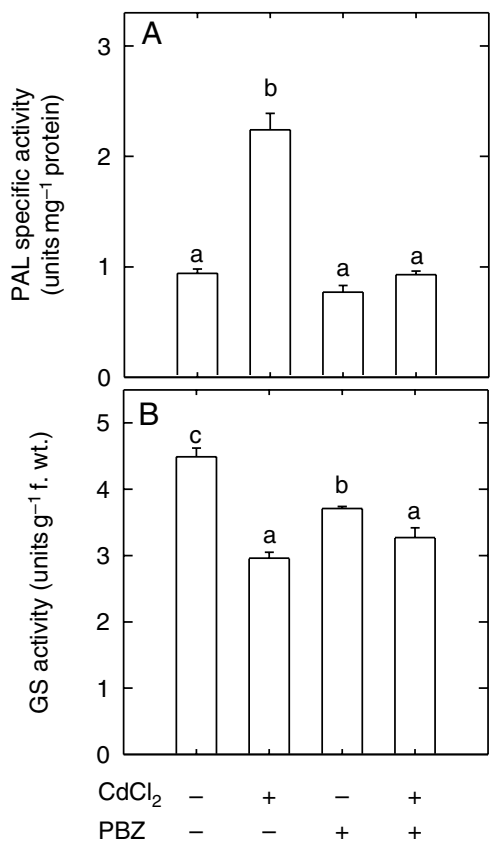

Fig. 5. Effect of $\mathrm{CdCl}_{2}$ on phenylalanine ammonia-lyase (PAL) specific activity (A) and glutamine synthetase (GS) activity (B) in the third leaves of $-P B Z$ and + PBZ rice seedlings ( $P B Z$, paclobutrazol). Rice seedlings were either untreated or treated with $\mathrm{CdCl}_{2}(1.5 \mathrm{mM})$ for 2 days. Bars indicate the standard error $(n=4)$. Values with the same letter are not significantly different at $P<0.05$. f. wt., fresh weight. 
recent review, Schützendübel and Polle (2002) suggested that the depletion of GSH was a critical step in Cd-induced AOS generation.

In previous work, it has been demonstrated that $\mathrm{Cd}$ can induce oxidative stress in rice leaves, characterized by an increase in the content of MDA (an indicator of lipid peroxidation) (Hsu and Kao 2004, Kuo and Kao 2004). In the present study, we observed that the increase in the content of MDA (Fig. 4) caused by $\mathrm{CdCl}_{2}$ was more pronounced in -PBZ leaves (Fig. 4C) than in +PBZ leaves (Fig. 4D).

The striking increase in lipid peroxidation seen in -PBZ leaves treated with $\mathrm{CdCl}_{2}$ (Fig. 4C) may reflect changes in the activities of antioxidant enzymes and contents of antioxidants. Previously, it has been observed that increases in SOD and POX specific activities in rice seedlings take place prior to the occurrence of $\mathrm{Cd}$ toxicity (decrease in protein content) (Kuo and Kao 2004). In this study, we showed that the increase in the specific activities of SOD and PO, caused by $\mathrm{CdCl}_{2}$, was more pronounced in -PBZ leaves than in + PBZ leaves (Fig. 6A,B). ASC is a major antioxidant in photosynthetic and non-photosynthetic tissues, which reacts directly with $\mathrm{AOS}$ and is utilized as a substrate for APX-catalysed $\mathrm{H}_{2} \mathrm{O}_{2}$ detoxification (Noctor and Foyer 1998). GSH is involved in ASC regeneration and also functions as a direct scavenger of AOS (Noctor and Foyer 1998). It is clear from Figs $6 \mathrm{C}$ and $6 \mathrm{D}$ that the decrease in ASC and GSH contents caused by $\mathrm{CdCl}_{2}$ was greater in -PBZ leaves than in +PBZ leaves. However, the depletion of ASC and GSH caused by $\mathrm{CdCl}_{2}$ could not be prevented completely in + PBZ leaves, suggesting that there was still some oxidative stress in +PBZ seedlings when exposed to $\mathrm{CdCl}_{2}$. All of the results presented here indicate that PBZ can be used to protect rice seedlings from oxidative stress caused by Cd toxicity.

\section{ABA accumulation in $+\mathrm{PBZ}$ leaves}

Previously, we have shown that an increase in endogenous $\mathrm{ABA}$ content is closely related to the $\mathrm{Cd}$

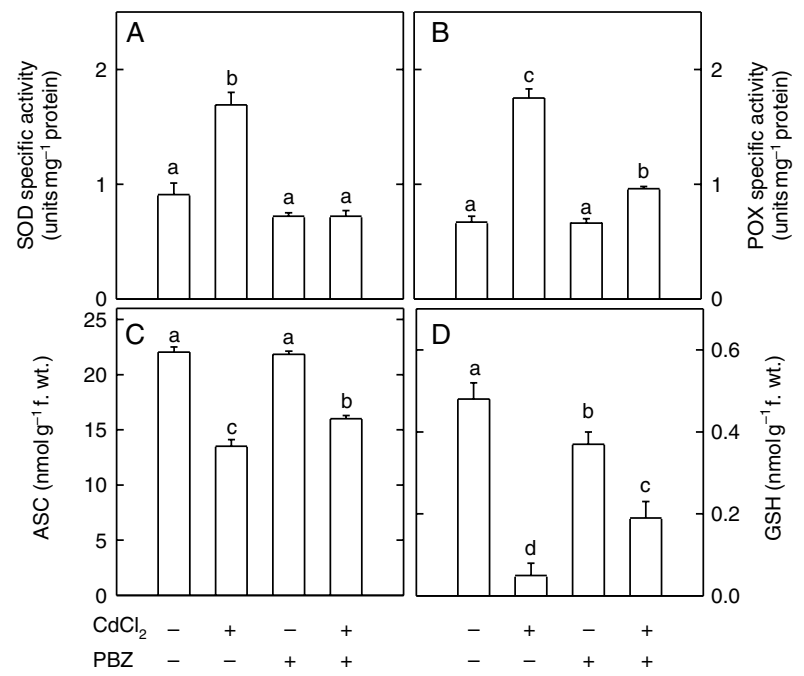

Fig. 6. Effect of $\mathrm{CdCl}_{2}$ on the specific activities of superoxide dismutase (SOD) (A) and peroxidase (POX) (B) and the contents of ascorbate (ASC) (C) and reduced glutathione (GSH) (D) in the third leaves of -PBZ and + PBZ rice seedlings (PBZ, paclobutrazol). Rice seedlings were either untreated or treated with $\mathrm{CdCl}_{2}(1.5 \mathrm{mM})$ for 2 days. Bars indicate the standard error $(n=4)$. Values with the same letter are not significantly different at $P<0.05$. f. wt., fresh weight.

tolerance of rice seedlings ( $\mathrm{Hsu}$ and Kao 2003a). In this study, we showed that $\mathrm{CdCl}_{2}$ treatment resulted in an increase in endogenous ABA in +PBZ leaves, but not in -PBZ leaves (Table 2), suggesting that ABA may play a role in $\mathrm{Cd}$ tolerance.

\section{Flu treatment}

The role of $\mathrm{ABA}$ in $\mathrm{PBZ}$-induced $\mathrm{Cd}$ tolerance was tested by using an inhibitor of ABA biosynthesis, Flu, which blocks the conversion of phytoene to phytofluene in the carotenoid biosynthesis pathway (KowalczykSchröder and Sandmann 1992). Flu was observed to inhibit the increase in $\mathrm{ABA}$ content (Fig. 7E) and to enhance $\mathrm{Cd}$ toxicity (as judged by biomass production and the contents of chlorophyll and protein) in +PBZ seedlings (Fig. 7A - D). The effect of Flu on Cd toxicity in +PBZ seedlings was reversed by the application of

Table 2. Effect of $\mathrm{CdCl}_{2}$ on abscisic acid (ABA) content, transpiration rate and $\mathrm{Cd}$ content in the third leaves of $-\mathrm{PBZ}$ and $+\mathrm{PBZ}$ rice seedlings. Rice seedlings were either untreated or treated with $\mathrm{CdCl}_{2}(1.5 \mathrm{mM})$ for 2 days. Values with the same letter are not significantly different at $P<0.05$. $\mathrm{d}$. wt., dry weight; f. wt., fresh weight; PBZ, paclobutrazol.

\begin{tabular}{|c|c|c|c|c|}
\hline Treatment & & ABA content (pmol g ${ }^{-1}$ f. wt.) & Transpiration rate $\left(\mathrm{mg} \mathrm{H}_{2} \mathrm{O}\right.$ seedling ${ }^{-1}$ day $^{-1}$ ) & Cd content ( $\mu \mathrm{g} \mathrm{g}{ }^{-1} \mathrm{~d}$. wt.) \\
\hline \multirow[t]{2}{*}{$-P B Z$} & $-\mathrm{CdCl}_{2}$ & $334.8 \pm 21.0(b)$ & $566 \pm 39.0(d)$ & $4.15 \pm 0.34(a)$ \\
\hline & $+\mathrm{CdCl}_{2}$ & $337.6 \pm 20.7(b)$ & $145 \pm 9.1(b)$ & $33.68 \pm 1.24(c)$ \\
\hline \multirow[t]{2}{*}{$+\mathrm{PBZ}$} & $-\mathrm{CdCl}_{2}$ & $255.1 \pm 27.6$ (a) & $456 \pm 20.5$ (c) & $5.33 \pm 0.84(a)$ \\
\hline & $+\mathrm{CdCl}_{2}$ & $328.1 \pm 19.5$ (b) & $55 \pm 6.1(\mathrm{a})$ & $20.13 \pm 0.71(b)$ \\
\hline
\end{tabular}




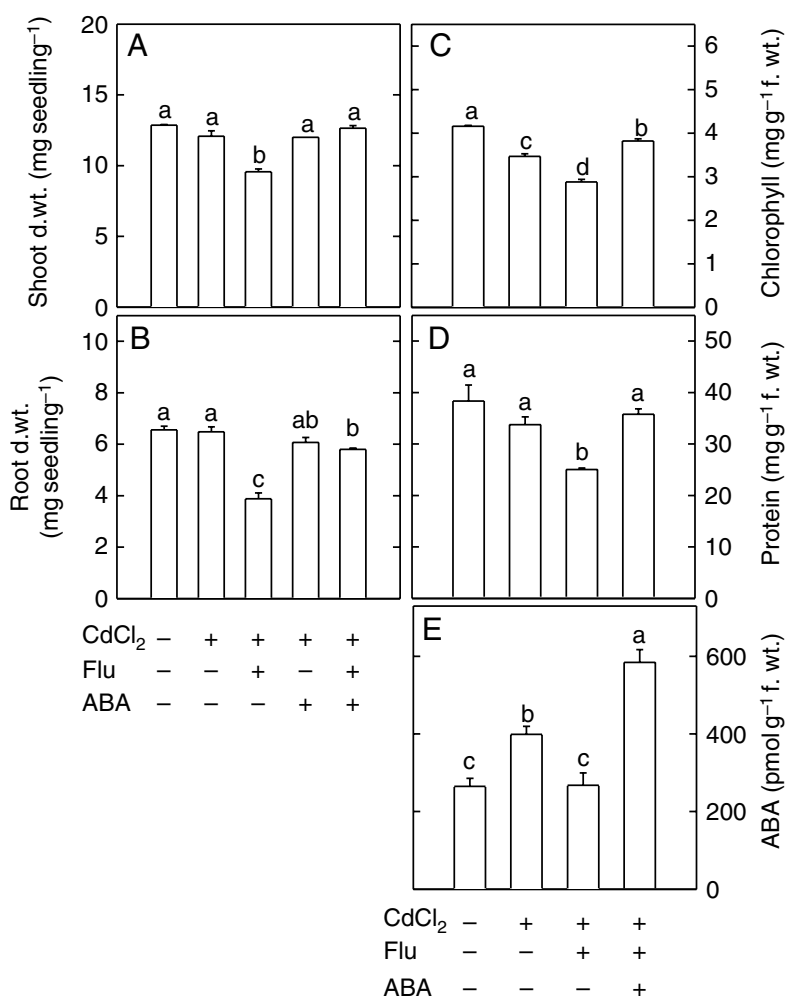

Fig. 7. Effect of fluridone (Flu, $0.2 \mathrm{mM})$ and abscisic acid (ABA) $(5 \mu \mathrm{M})$ on the dry weight (d. wt.) of shoot $(A)$ and $\operatorname{root}(B)$ and the contents of chlorophyll (C), protein (D) and $A B A(E)$ in the third leaves of $+P B Z$ rice seedlings (PBZ, paclobutrazol) treated or not with $\mathrm{CdCl}_{2}(1.5 \mathrm{mM})$. All measurements were made 2 days after treatment. Bars indicate the standard error $(n=4)$. Values with the same letter are not significantly different at $P<0.05$. f. wt., fresh weight.

ABA (Fig. 7A - D). It should be noted that $\mathrm{CdCl}_{2}+\mathrm{ABA}$ treatment resulted in a similar biomass production as $\mathrm{CdCl}_{2}$ treatment (Fig. 7A,B). These results suggest that the $\mathrm{ABA}$ content in the leaves of $+\mathrm{PBZ}$ seedlings treated with $\mathrm{CdCl}_{2}$ is sufficient to exert an effect on biomass production.

\section{Cd content}

Table 2 shows the effect of $\mathrm{CdCl}_{2}$ on the $\mathrm{Cd}$ content in PBZ and +PBZ leaves. The Cd content in +PBZ leaves increased about four-fold after Cd treatment (Table 2). However, an eight-fold increase in $\mathrm{Cd}$ content in $\mathrm{Cd}$ treated -PBZ leaves was observed (Table 2). Flu treatment caused an increase in $\mathrm{Cd}$ content in the leaves of +PBZ seedlings exposed to $\mathrm{CdCl}_{2}$ (Fig. 8A). The effect of Flu on the $\mathrm{Cd}$ content in Cd-treated leaves of + PBZ seedlings was reversed by the application of $A B A$ (Fig. 8A).

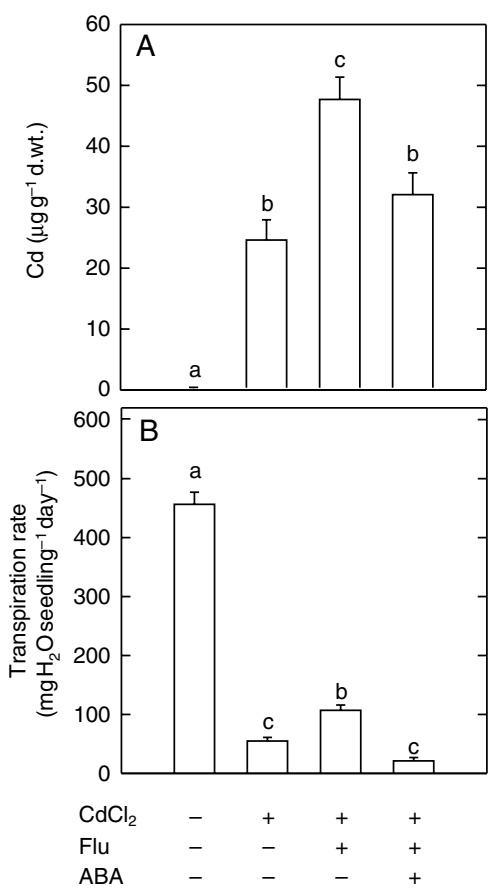

Fig. 8. Effect of fluridone (Flu, $0.2 \mathrm{mM})$ and abscisic acid (ABA) $(5 \mu \mathrm{M})$ on the $\mathrm{Cd}$ content $(\mathrm{A})$ in the third leaves and the transpiration rate $(B)$ of + PBZ rice seedlings (PBZ, paclobutrazol) treated or not with $\mathrm{CdCl}_{2}$ $(1.5 \mathrm{mM})$. The $\mathrm{Cd}$ content was measured 2 days after treatment, and the transpiration rate was measured 1 day after treatment. Bars indicate the standard error $(n=4)$. Values with the same letter are not significantly different at $P<0.05$. d. wt., dry weight.

\section{Transpiration rate}

In the absence of $\mathrm{CdCl}_{2}$, the transpiration rate of $-\mathrm{PBZ}$ seedlings was observed to be higher than that of + PBZ seedlings (Table 2). Cd treatment decreased the transpiration rate in both $-\mathrm{PBZ}$ and + PBZ seedlings (Table 2). However, the decrease in the transpiration rate in response to $\mathrm{CdCl}_{2}$ was less pronounced in -PBZ seedlings than in +PBZ seedlings (Table 2). Flu treatment resulted in an increase in the transpiration rate in + PBZ seedlings treated with $\mathrm{CdCl}_{2}$ (Fig. 8B). The effect of Flu on the transpiration rate in +PBZ seedlings treated with $\mathrm{CdCl}_{2}$ was reversed by $\mathrm{ABA}$ application (Fig. 8B).

\section{Discussion}

Cd causes biomass reduction (Chen and Kao 1995), chlorophyll and protein loss (Hsu and Kao 2003a), $\mathrm{NH}_{4}{ }^{+}$accumulation (Hsu and Kao 2003b) and oxidative stress (Kuo and Kao 2004) in rice seedlings. In the present study, we evaluated $\mathrm{Cd}$ toxicity by the decrease in biomass production, decrease in chlorophyll and protein content, increase in $\mathrm{NH}_{4}{ }^{+}$content and 
induction of oxidative stress. On the basis of these criteria, we demonstrated that PBZ applied to seeds was able to protect rice seedlings from $\mathrm{Cd}$ toxicity. The protective effect of uniconazole, a member of the triazole family, against $\mathrm{Cd}$ stress has also been described previously (Singh 1993).

The present study indicated that $A B A$ was involved in the $\mathrm{Cd}$ tolerance of $+\mathrm{PBZ}$ seedlings. This conclusion was based on the following observations: (1) the increase in the endogenous $A B A$ content in response to $\mathrm{Cd}$ in +PBZ leaves was more pronounced than that in -PBZ leaves (Table 2); (2) Flu treatment led to a decrease in the $\mathrm{ABA}$ content, as well as $\mathrm{Cd}$ tolerance, of +PBZ seedlings (Fig. 7); and (3) the effect of Flu on the $\mathrm{Cd}$ toxicity of $+\mathrm{PBZ}$ seedlings was reversed by the application of ABA (Fig. 7). These results suggest that the regulation of endogenous $A B A$ biosynthesis under $\mathrm{Cd}$ stress is correlated with the tolerance of + PBZ seedlings. As Flu is an inhibitor of ABA biosynthesis through the carotenoid pathway (Kowalczyk-Schröder and Sandmann 1992), the effects of this inhibitor on +PBZ leaves may imply that the ABA biosynthesis pathway in response to $\mathrm{Cd}$ appears to be the same as that established in other stress conditions (Zeevaart and Creelman 1988, Seo and Koshiba 2002). In addition, the defect in ABA accumulation in -PBZ leaves may account for the $\mathrm{Cd}$ intolerance of -PBZ seedlings.

Plants have a range of potential mechanisms at the cellular level that may be involved in the detoxification of, and thus tolerance to, heavy metals. These all appear to be involved primarily in avoiding the build-up of toxic concentrations at sensitive sites within the cell, and thus preventing damaging effects (Hall 2002). In this context, reduced translocation of $\mathrm{Cd}$ to the shoot appears to be a possible mechanism of $\mathrm{Cd}$ tolerance in the shoot. Cd translocation to the shoot has been suggested to be driven by transpiration (Salt et al. 1995). Cd has been shown to decrease the transpiration rate in several plants (Bazzaz et al. 1974, Kirkham 1978, Lamoreaux and Chaney 1978, Hagemeyer et al. 1986, Schlegel et al. 1987, Hsu and Kao 2003a). Here, we also observed that $\mathrm{Cd}$ treatment decreased the transpiration rate of - PBZ and +PBZ seedlings (Table 2). Cd treatment decreased the transpiration rate in -PBZ and +PBZ seedlings to about $74 \%$ and $88 \%$ of the control value, respectively (Table 2 ). Thus, the decrease in the transpiration rate of -PBZ seedlings (which were unable to accumulate $A B A$ ) caused by $C d$ was less than that in + PBZ seedlings (which accumulated ABA), and consequently resulted in a higher $\mathrm{Cd}$ content in -PBZ than in + PBZ seedlings (Table 2). The effect of Flu on +PBZ seedlings indicated that not only was $\mathrm{ABA}$ biosynthesis blocked, but the transpiration rate and $\mathrm{Cd}$ content were increased (Figs 7E and 8). Furthermore, the effect of Flu on the transpiration rate and $\mathrm{Cd}$ content of $+\mathrm{PBZ}$ seedlings was reversed by the application of ABA (Fig. 8). It appears that the increase in endogenous $A B A$ content is closely related to the $\mathrm{Cd}$ tolerance of $+\mathrm{PBZ}$ seedlings. $A B A$ may exert its regulatory effect on the transpiration rate, decreasing the translocation of $\mathrm{Cd}$ to the shoot.

Stress-tolerant plants often grown more slowly than stress-intolerant plants. It has been hypothesized that +PBZ plants show a better quality of growth than -PBZ plants under stress conditions as a result of the slower growth rate or metabolism of the former (Abou El-Khashab et al. 1997). Thus, the possibility that $A B A$ may also exert its effect on the metabolism of +PBZ seedlings cannot be excluded.

PBZ inhibits GA biosynthesis (Graebe 1987, Rademacher et al. 1987). It has been shown that the application of GA counters both the growth inhibitory and stress-protective effects of triazoles (Guoping 1997, Vettakkorumakankav et al. 1999, Sarkar et al. 2004). An interesting question then arises: is a decrease in both endogenous GA content and shoot length essential to enhance $\mathrm{Cd}$ tolerance in rice seedlings? Future work will focus on this question by examining the $\mathrm{Cd}$ tolerance in GA-responsive and GA non-responsive dwarf mutants of rice.

Acknowledgements - This work was supported financially by the National Science Council of the Republic of China.

\section{References}

Abou El-Khashab AM, El-Sammak AF, Elaidy AA, Salama MI (1997) Paclobutrazol reduces some negative effects of salt stress in peach. J Am Soc Hort Sci 122: 43-46

Bazzaz FA, Rolfe GL, Carlson RW (1974) Effect of cadmium on photosynthesis and transpiration of excised leaves of corn and sunflower. Physiol Plant 31: 373-377

Bradford MM (1976) A rapid and sensitive method for the quantitation of microgram quantities of protein utilizing the principle of protein-dye binding. Anal Biochem 72: 248-254

Chen SL, Kao CH (1995) Cd induced changes in proline level and peroxidase activity in roots of rice seedlings. Plant Growth Regul 17: 67-71

Chu C, Lee TM (1989) The relationship between ethylene biosynthesis and chilling tolerance in seedlings of rice (Oryza sativa). Bot Bull Acad Sin 30: 263-273

Cox DA, Keever GJ (1988) Paclobutrazol inhibits growth of zinnia and geranium. Hortscience 23: 1029-1030

Das P, Samantaray S, Rout GR (1997) Studies on cadmium toxicity in plants: a review. Environ Pollut 98: 29-36 
Davis TD, Curry EA (1991) Chemical regulation of vegetative growth. Crit Rev Plant Sci 10: 151-188

Davis TD, Steffens GL, Sankhla N (1988) Triazole plant growth regulator. Hort Rev 10: 63-105

Fletcher RA, Hosfsta G (1990) Improvement of uniconazoleinduced protection in wheat seedlings. J Plant Growth Regul 9: 207-212

Gilley A, Fletcher RA (1998) Gibberellin antagonizes paclobutrazol-induced stress protection in wheat seedlings. J Plant Physiol 153: 200-207

Givan CV (1979) Metabolic detoxification of ammonia in tissues of higher plants. Phytochemistry 18: 375-382

Graebe JE (1987) Gibberellin biosynthesis and control. Annu Rev Plant Physiol 38: 419-465

Greger M, Johansson M (1992) Cadmium effects on leaf transpiration of sugar beet (Beta vulgaris). Physiol Plant 86: 465-473

Guoping E (1997) Gibberellic acid modifies some growth and physiologic effects of paclobutrazol $\left(\mathrm{PP}_{333}\right)$ on wheat. J Plant Growth Regul 16: 21-25

Guy CL (1990) Cold acclimation and freezing stress tolerance: role of protein metabolism. Annu Rev Plant Physiol Plant Mol Biol 41: 187-223

Hagemeyer J, Kahle M, Breckle SW (1986) Cadmium in Fagus sylvatica L. trees and seedlings: leaching, uptake and interconnection with transpiration. Water Air Soil Pollut 29: 347-359

Hahlbrock R, Grisebach H (1979) Enzymic controls in the biosynthesis of lignin and flavonoids. Annu Rev Plant Physiol 30: 105-130

Hall JL (2002) Cellular mechanisms for heavy metal detoxification and tolerance. J Exp Bot 53: 1-11

Heath RL, Packer L (1968) Photoperoxidation in isolated chloroplasts. I. Kinetics and stoichiometry of fatty acid peroxidation. Arch Biochem Biophys 125: 189-198

Hsu YT, Kao CH (2003a) Role of abscisic acid in cadmium tolerance of rice (Oryza sativa L.) seedlings. Plant Cell Environ 26: 867-874

Hsu YT, Kao CH (2003b) Accumulation of ammonium ion in cadmium tolerant and sensitive cultivars of Oryza sativa. Plant Growth Regul 39: 271-276

Hsu YT, Kao CH (2004) Cadmium toxicity is reduced by nitric oxide in rice leaves. Plant Growth Regul 42: $227-238$

Hyodo H, Fujinami $H$ (1989) The effect of 2,5-nobornadiene on the induction of the activity of 1 -aminocyclopropane-1-carboxylate synthase and of phenylalanine ammonia-lyase in wounded mesocarp tissue of Cucurbita maxima. Plant Cell Physiol 30: 857-860

Kirkham MB (1978) Water relations of cadmium-treated plants. J Environ Qual 7: 334-336

Kowalczyk-Schröder S, Sandmann G (1992) Interaction of fluridone with phytoene desaturation of Aphanocapsa. Pestic Biochem Physiol 42: 7-12
Kraus TE, Fletcher RA (1994) Paclobutrazol protects wheat seedlings from heat and paraquat injury. Is detoxification of active oxygen involved? Plant Cell Physiol 35: 45-52

Kraus TE, Mckersie BD, Fletcher RA (1995) Paclobutrazolinduced tolerance of wheat leaves to paraquat may involve increased antioxidant enzyme activity. J Plant Physiol 145: 570-576

Kuo MC, Kao CH (2004) Antioxidant enzyme activities are upregulated in response to cadmium in sensitive, but not in tolerant, rice (Oryza sativa L.) seedlings. Bot Bull Acad Sin 45: 291-299

La Rosa PC, Hasegawa PM, Rhodes D, Clithero JM, Watad A, Bressan RA (1987) Abscisic acid stimulated osmotic adjustment and its involvement in adaptation of tobacco cells to $\mathrm{NaCl}$. Plant Physiol 85: 174-181

Lamoreaux RL, Chaney WR (1978) The effect of cadmium on net photosynthesis, transpiration and dark respiration of excised silver maple leaves. Physiol Plant 43: 231-236

Laws MY, Stephen Y, Charles A, Halliwell B (1983) Glutathione and ascorbic acid in spinach (Spinacia oleracea) chloroplasts. The effect of hydrogen peroxide and paraquat. Bicohem J 210: 899-903

Lee EH, Byun JK, Wilding SJ (1985) A new gibberellin biosynthesis inhibitor, paclobutrazol $\left(\mathrm{PP}_{333}\right)$, confers increased $\mathrm{SO}_{2}$ tolerance on snap bean plants. Environ Exp Bot 25: 265-275

Lee T-M, Lur H-S, Chu C (1993) Role of abscisic acid in chilling tolerance of rice (Oryza sativa L.) seedlings. I. Endogenous abscisic acid levels. Plant Cell Environ 16: 481-490

Lin CC, Kao CH (1996) Disturbed ammonia assimilation is associated with growth inhibition of roots in rice seedlings caused by $\mathrm{NaCl}$. Plant Growth Regul 18: 223-238

Lin D, Lur H-S, Chu C (2001) Effect of abscisic acid on ozone tolerance of rice (Oryza sativa L.) seedlings. Plant Growth Regul 35: 295-300

Lurie S, Ronen R, Lipsker Z, Aloni B (1994) Effects of paclobutrazol and chilling temperatures on lipids, antioxidants and ATPase activity of plasma membrane isolated from green bell pepper fruits. Plant Physiol 91: 593-598

MacAdam JW, Nelson CJ, Sharp RE (1992) Peroxidase activity in the leaf elongation zone of tall fescue. Plant Physiol 99: 872-878

Miflin BJ, Lea PJ (1976) The pathway of nitrogen assimilation in plants. Phytochemistry 15: 873-885

Noctor G, Foyer CH (1998) Ascorbate and glutathione: keeping active oxygen under control. Annu Rev Plant Physiol Plant Mol Biol 49: 249-279

Oaks A, Stulen J, Jones K, Winspear MJ, Booesel IL (1980) Enzymes of nitrogen assimilation in maize roots. Planta 148: 477-484

Paoletti F, Aldinucci D, Mocali A, Capparini A (1986) A sensitive spectrophotometric method for the determination of superoxide dismutase activity in tissue extracts. Anal Biochem 154: 536-541 
Pinhero RG, Fletcher RA (1994) Paclobutrazol and uniconazole protect corn seedlings from high and low temperature stresses. Plant Growth Regul 15: $47-53$

Pinhero RG, Rao MV, Paliyath G, Murr DP, Fletcher RA (1997) Changes in activities of antioxidant enzymes and their relationship to genetic and paclobutrazol-induced chilling tolerance of maize seedlings. Plant Physiol 114: 695-704

Rademacher W, Fritsch H, Graebe JE, Sauter A, Jung J (1987) Tetcyclacis and triazole plant growth retardants: their influence on the biosynthesis of gibberellins and other metabolic processes. Pestic Sci 21: 241-252

Razel RA, Ellis S, Singh S, Lewis NG, Towers GHN (1996) Nitrogen recycling in phenylpropanoid metabolism. Phytochemistry 41: 31-35

Sakurai N, Katayama Y, Yamaya T (2001) Overlapping expression of cytosolic glutamine synthetase and phenylalanine ammonia-lyase in immature leaf blades of rice. Physiol Plant 113: 400-408

Salt DE, Prince RC, Pickering IJ, Raskin I (1995) Mechanism of cadmium mobility and accumulation in Indian mustard. Plant Physiol 109: 1427-1433

Sanitá di Toppi L, Gabbrielli R (1999) Response to cadmium in higher plants. Environ Exp Bot 41: 105-130

Sarkar S, Perras MR, Falk DE, Zhang R, Pharis RP, Flethcher RA (2004) Relationship between gibberellins, height, and stress tolerance in barley (Hordeum vulgare L.) seedlings. Plant Growth Regul 42: 125-135

Schlegel H, Godbold DL, Hüttermann A (1987) Whole plant aspects of heavy metal induced changes in $\mathrm{CO}_{2}$ uptake and water relations of spruce (Picea abies) seedlings. Physiol Plant 69: 265-270

Schützendübel A, Polle A (2002) Plant responses to abiotic stresses: heavy metal-induced oxidative stress and protection by micorrhization. J Exp Bot 53: 1351-1365

Seo M, Koshiba T (2002) Complex regulation of ABA biosynthesis. Trends Plant Sci 7: 41-48

Singh VP (1993) Uniconazole (S-3307) induced cadmium tolerance in wheat. J Plant Growth Regul 12: 1-3

Smith IK (1985) Stimulation of glutathione synthesis in photorespiring plants by catalase inhibitors. Plant Physiol 79: 1044-1047

Van Heerden PS, Tower GHN, Lewis NG (1996) Nitrogen metabolism in lignifying Pinus taeda cell cultures. J Biol Chem 271: 12 350-12 355

Vettakkorumakankav NN, Falk D, Saxena P, Fletcher RA (1999) A crucial role for gibberellins in stress protection of plants. Plant Cell Physiol 40: 542-548

Wagner GJ (1993) Accumulation of cadmium in crop plants and its consequence to human health. Adv Agron 51: 173-212

Walker-Simmons M (1987) ABA levels and sensitivity in developing wheat embryos of sprouting resistant and susceptible cultivars. Plant Physiol 84: 61-66

Weatherburn MW (1967) Phenol-hypochloride reaction for determination of ammonia. Anal Chem 39: 971-974

Webb JA, Fletcher RA (1996) Paclobutrazol protects wheat seedlings from injury due to waterlogging. Plant Growth Regul 18: 201-206

Whitaker BD, Wang CY (1987) Effect of paclobutrazol and chilling on leaf membrane lipids in cucumber seedlings. Physiol Plant 70: 404-411

Wintermans JFGM, De Mots A (1965) Spectrophotometric characteristics of chlorophyll $\mathrm{a}$ and $\mathrm{b}$ and their pheophytins in ethanol. Biochim Biophys Acta 109: 448-453

Zeevaart JAD, Creelman RA (1988) Metabolism and physiology of abscisic acid. Annu Rev Plant Physiol Plant Mol Biol 39: 439-473 